\title{
PSYCHOSOCIAL ADJUSTMENT OF FIRST YEAR GYMNASIUM STUDENTS DEPENDING ON GENDER
}

\author{
Šarūnas Klizas ${ }^{1}$, Irina Kliziené2 ${ }^{2}$ Vitas Linonis ${ }^{2}$, Daina Miliauskiené $\dot{e}^{3}$ \\ Lithuanian Academy of Physical Education ${ }^{1}$, Kaunas, Lithuania. \\ Kaunas University of Technology', Kaunas, Lithuania \\ Special School of Prienai ${ }^{3}$, Prienai, Lithuania
}

\begin{abstract}
Research background and hypothesis. The data of students' national academic achievements confirmed that high achievements were related to good well-being at school. Most attention should be paid to first year gymnasium students because especially great differences were established in the academic achievements of those who evaluated school microclimate favorably and unfavorably. We hypothesized that the level of psychosocial adjustment of female first year gymnasium students would be higher than that of male students.

Research aim. The aim of the present study was to establish psychosocial adjustment of first year gymnasium students depending on their gender.

Research methods. The sample included 362 first year gymnasium students, girls $(\mathrm{n}=198)$ and boys $(\mathrm{n}=164)$. They were 14-16 years of age. The Rogers and Dymond's questionnaire was chosen for the evaluation of psychosocial adjustment (Rogers, Dymond, 1954). It was translated into the Lithuanian language and adapted for the Lithuanian population (Klizas, 2009). Besides the psychosocial adjustment subscale, we analyzed other subscales (self-esteem, evaluation of others, emotional comfort, integrity, domination, avoidance of problem) as well which helped reveal the person's psychosocial adjustment.

Research results. Analyzing the level of gymnasium students psychosocial adjustment in the aspect of gender, we established statistically significant difference in the avoidance of problems $(t=-3.19 ; \mathrm{p}<0.05)$. We established that the level of negative evaluation of others for boys and girls was statistically significant $\left(\chi^{2}=10.71 ; \mathrm{df}=2\right.$; $\mathrm{p}<0.05$ ). The evaluation of the level of emotional discomfort for boys and girls revealed a statistically significant difference in the aspect of gender $\left(\chi^{2}=12.49 ; \mathrm{df}=2 ; \mathrm{p}<0.05\right)$.

Discussion and conclusions. We established that psychosocial adjustment of first year gymnasium students was of low level. Such components of psychosocial adjustment as adjustment, evaluation of others, emotional comfort, integrity, domination and avoidance of problems were of low level, and only self-esteem was moderate. In the aspect of gender, we revealed a statistically significant difference in the avoidance of problems $(p<0.05)$. The avoidance level of girls in the first year of the gymnasium was higher than that of boys. But for boys, the levels of adjustment, evaluation of others, emotional comfort, integrity, domination were higher than those of girls. Self-esteem for girls was higher than that of boys; however, no statistically significant difference was found.
\end{abstract}

Keywords: school (adjustment) microclimate, emotional comfort, avoidance of problems.

\section{INTRODUCTION}

$\mathrm{P}$ sychosocial adjustment of a personality as a special phenomenon of an individual in social interrelations covers multiple aspects in itself, some of which are related to the standards of the society while others are connected with the behavioral norms of the personality. All of them are equally important for the peculiarities of the personality values and its needs (Malinauskas, 2006). During the whole life of an individual, value orientation and development of needs 
acquire particular traits which at some moments of human life contribute to efficient adaptation while sometimes they complicate the situation by involving specific peculiarities. The age group of adolescence is unique since it shows the "flash" of the development of social, psychological and physiological activeness of the personality (Barkauskaite, 2000). Psychosocial adjustment may be determined as a mutual process taking place between an individual and his/her environment, and the active adjustment of an individual to the altering environment and conditions of living (Juodraitis, 2004). Psychosocial adjustment during adolescence may be interpreted as the strife of adolescents to discover their place, to alter in order to adjust, and to alter the place in order to adapt it to themselves. Thus, it is essential to explore the middle school age during which the "flash" of motoric needs takes place together with the active sexual maturation as well as rapid growth and development of all the organs and systems of the body.

On the basis of the exploration of publications and research at the recent time, one may claim that the issue of psychosocial adjustment of students of the age of adolescence raises increasing worries of pedagogues and the general society (Malinauskas et al., 2008). These students whose adaptation at school and among peers is not fluent and those who experience hard situations in their family and/or home environment, later on transfer their problems to the world of adults (Juodraitis, 2004). It has been established that schoolchildren experience difficulties while adjusting to the altered environment and they undergo adaptation crisis. The age period of the first year gymnasium students is adolescence, and in this period schoolchildren are most vulnerable by the social environment, so adjustment difficulties at school are linked to further adaptation of schoolchildren in the society. Personal ability to adapt to changes in life and good psychosocial adjustment under the conditions of constantly changing situations are the indicators of the quality of life. If this process is not successful, there is absolutely no balance between the individual and their environment, which interferes with the individual development and meeting their needs (Harrison, Jagelavičius, 1999). Students' well-being at school, i.e. their evaluation of school climate is an important part of school education quality. It is obvious that school that threatens and hinders students' motivation and promotes bullying is not a good school, even if the academic achievements of schoolchildren are high (Gudynas et al., 2009). Thus, the accessibility of general education should be analyzed in the context not only of schoolchildren's achievements, but also their psychosocial adjustment at school.

The analysis of other studies (Jia et al., 2009; Adeyemo, Ogundokum, 2010) and their publications suggests that the problem of schoolchildren's psychosocial adjustment at school still worries the majority of teachers and the society. Difficulties in psychosocial adjustment in the gymnasium can influence not only schoolchildren's academic achievements, but also their mental and emotional health. At present problems of schoolchildren's adjustment and anxiety are common. Well-being of a student is believed to be one of the most important factors deciding the level of their psychosocial adjustment, attitudes towards school and learning. Poor well-being and continuous anxiety lower child's intellectual abilities, working capacity, initiative, hinders communication with others, and thus provokes conflicts between the adolescent and the new environment (Parker, Neuharth-Pritchett, 2009). Research results have shown that successful school adjustment is determined by the safety of schoolchildren because when children feel safe and surrounded by warm and pleasant environment, the process of school adjustment will be smooth (Midgley et al., 2000). Success in psychosocial adjustment also depends on the relationship between schoolchildren and teachers (Barber, Olsen, 2004). Teachers who not only interest children in their subjects but themselves show interest in schoolchildren and their life at school have a positive effect on their mutual aims and methods of work. Help for students is the indicator of teachers' behavior at school of utmost importance. It helps to understand the changes in schoolchildren's learning, personal and interpersonal relations after changing school. For this reason teachers have to help first year gymnasium students to perceive that in a new community it is very important to know every member in the classroom, the organization culture, values, and community aims because all those things ensure faster adaptation in a new environment (Barber, Olsen, 2004).

The data of students' national academic achievements confirmed that high achievements were related to good well-being at school. If students felt well at school (they liked to be and learn there, they did not feel lonely, they were liked by other students, they had possibilities to discus 
school rules and they felt in their own place), their academic achievements were statistically significantly higher compared to those students who did not feel so well (Bigelienè, Uginčienè, 2008). Most attention should be paid to first year gymnasium students because especially great differences have been established in the academic achievements of those who evaluated school microclimate favorably and unfavorably (Gudynas et al., 2009).

The aim of the present study was to establish psychosocial adjustment of first year gymnasium students depending on their gender.

We hypothesized that the level of psychosocial adjustment of female first year gymnasium students would be higher than that of male students.

\section{RESEARCH METHODS}

Using the strategy of random sampling we selected first year gymnasium students from three city and three regional gymnasiums. The sample included 362 first year gymnasium students, girls $(\mathrm{n}=198)$ and boys $(\mathrm{n}=164)$. They were $14-16$ years of age. While organizing the research we distributed 419 questionnaires. We received 392 questionnaires as 27 students refused to participate in the research. After the initial calculations and the application of the falsity scale estimates, 362 questionnaires were suitable for the analysis (30 questionnaires were eliminated from the analysis as unsuitable).

We obtained oral permission to carry out our research from the gymnasium administration, teachers and students. The survey was conducted in the morning, during the lessons. Before the research the students were explained the aim of the research and the order of filling in the questionnaire. The procedure of filling in the questionnaire took place in the classroom and lasted about 40 minutes. The questionnaires were filled in personally, and no help was needed from the researcher.

Instruments. The Rogers and Dymond's questionnaire was chosen for the evaluation of psychosocial adjustment (Rogers, Dymond, 1954). It was translated into the Lithuanian language and adapted for the Lithuanian population (Klizas, 2009). The Rogers and Dymond's questionnaire consisted of 101 items and the range of responses was a 7-point scale. The respondents had to choose one answer out of seven possible variants: This is definitely not about me-0; This does not look like me - 1; I doubt that this could be applied to me-2; I do not dare to apply it to me-3; This is similar to me, but I am not sure - 4; This is similar to me - 5; This is definitely about me -6 . The results were evaluated as follows: up to 68 points - low level of adjustment, 68-170 points - moderate level of adjustment, and higher than 170 points - high level of adjustment.

The main subscale, which best revealed the nature of psychosocial adjustment, was "adjustment" subscale (internal validity of this subscale (Cronbach's alpha) was 0.76). The subscale included the 67 items of the questionnaire. Besides the psychosocial adjustment subscale, we analyzed other subscales (self-esteem, evaluation of others, emotional comfort, integrity, domination, avoidance of problems) as well which helped reveal the person's psychosocial adjustment. The subscale "self-esteem" consisted of 18 items. Cronbach's alpha of the subscale "self-esteem" was 0.72 for the present sample. The subscale "dominance" consisted of nine items. Cronbach's alpha of the subscale "dominance" was 0.72 for the present sample.

Statistical analysis. Data analysis was performed using the Statistical Package for Social Sciences (SPSS) version 17. Kolmogorov-Smirnov test was applied for normality verification. The nonparametric chi-square test was used for the statistical analysis of the data. The distribution of the Rogers and Dymond's questionnaire data differed from the normal distribution statistically insignificantly. Consequently, t-test for independent samples was used for the significance of the difference between the means of groups. We chose the significance level of 0.05 .

\section{RESEARCH RESULTS}

The authors of this method (K. Rogers and R. Dymond) designed their own model of psychosocial adjustment, thus besides the main adjustment subscale they included other subscales which in their opinion help reveal psychosocial adjustment of a person. For the validity of the subscales, correlation analysis was performed (Table), which produced statistically significant and theoretically meaningful correlations between subscales. Strong and statistically significant relation was found between adjustment and selfesteem subscales $(\mathrm{r}=0.86 ; \mathrm{p}<0.001)$, as well as between adjustment and integrity subscales 
$(\mathrm{r}=0.83 ; \mathrm{p}<0.001)$. Strong and statistically significant relation was established between the subscales of adjustment and evaluation of others $(\mathrm{r}=0.68 ; \mathrm{p}<0.001)$, and adjustments and emotional comfort $(r=0.76 ; p<0.001)$. We can claim that successful psychosocial adjustment is influenced by positive self-esteem and integrity, as well as experienced emotional comfort and evaluation of others. Week correlation was established between adjustment and wish to dominate $(\mathrm{r}=0.34$; $\mathrm{p}<0.001$ ). It should be noted that we established a negative essential correlation between adjustment and avoiding problems $(\mathrm{r}=-0.41 ; \mathrm{p}<0.001)$. It shows that when a person avoids problems, it is difficult to judge about successful psychosocial adjustment.

Statistically significant strong relations were established between personal self-esteem and emotional comfort $(r=0.61 ; p<0.001)$, integrity $(r=0.71 ; p<0.001)$, and the relation between selfesteem and evaluation of others was statistically significant and essential $(\mathrm{r}=0.5 ; \mathrm{p}<0.001)$. We can argue that personality with positive selfesteem experiences emotional comfort, integrity, positively evaluates others and is not inclined to dominate, which ensures high levels of psychosocial adjustment.

Correlation analysis revealed that there were strong and very strong essential, statistically significant relations between all subscales of psychosocial adjustment, which suggests that in K. Rogers and R. Dymond's model of psychosocial adjustment, not only the main subscale of adjustment is important, other subscales are no less important as well: self-esteem, evaluation of others, emotional comfort, avoidance of problems, integrity and domination.

Analyzing the level of gymnasium students' psychosocial adjustment in the aspect of gender, we established statistically significant difference in the avoidance of problems $(\mathrm{t}=-3.19 ; \mathrm{p}<0.05)$. The level of avoidance of problems among the girls was higher (14.42 \pm 4.79 points) compared to boys (12.78 \pm 4.99 points). It was established that the levels of adjustment, evaluation of others, emotional comfort, integrity and domination for boys were higher than those for girls. Self-esteem for girls was higher than that for boys, but we did not establish statistically significant difference (Figure 1).

The differences in the levels of negative evaluation between girls and boys were statistically significant $(\chi 2=10.71 ; \mathrm{df}=2 ; \mathrm{p}<0.05)$ (Figure 2). The average level of negative evaluation of others was more common among girls (56.6 \%) compared to boys $(40.2 \%)$. Low level of negative evaluation of others dominated more among boys (59.8\%), compared to girls $(42.9 \%)$.

The evaluation of the level of emotional discomfort for boys and girls revealed a statistically significant difference in the aspect of gender $\left(\chi^{2}=12.49 ; \mathrm{df}=2 ; \mathrm{p}<0.05\right)$. The majority of girls (65.7\%) experienced the average level of emotional discomfort, and the majority of boys (51.8\%) the low level of it. Almost half of the respondents (48.2\%) demonstrated moderate level of emotional discomfort. Low level of emotional discomfort was characteristic of $33.8 \%$ of girls. High level of discomfort was expressed only by $0.5 \%$ of girls (Figure 3).

\begin{tabular}{|l|l|c|c|c|c|c|c|}
$\begin{array}{l}\text { Table 1. Inter-correlation } \\
\text { indices of adjustment } \\
\text { scales }\end{array}$ & $\begin{array}{c}\text { Adjustment } \\
\text { subscales }\end{array}$ & Self-esteem & $\begin{array}{c}\text { Evaluation } \\
\text { of others }\end{array}$ & $\begin{array}{c}\text { Emotional } \\
\text { comfort }\end{array}$ & Integrity & Domination & $\begin{array}{c}\text { Avoidance of } \\
\text { problems }\end{array}$ \\
\cline { 2 - 8 } & Adjustment & $0.86(* *)$ & $0.68(* *)$ & $0.76(* *)$ & $0.83(* *)$ & $0.34(* *)$ & $-0.41(* *)$ \\
\hline & Self-esteem & 1 & $0.5(* *)$ & $0.61(* *)$ & $0.71(* *)$ & $0.21(* *)$ & $-0.26(* *)$ \\
\hline $\begin{array}{l}\text { Evaluation of } \\
\text { others }\end{array}$ & $0.5(* *)$ & 1 & $0.47(* *)$ & $0.45(* *)$ & -0.05 & $-0.32(* *)$ \\
\hline $\begin{array}{l}\text { Emotional } \\
\text { comfort }\end{array}$ & $0.61(* *)$ & $0.47(* *)$ & 1 & $0.6(* *)$ & $0.35(* *)$ & $-0.33(* *)$ \\
\hline $\begin{array}{l}\text { Note. ** } \\
\text { significant } \\
(\mathrm{p}<0.001) .\end{array}$ & Integrity & $0.71(* *)$ & $0.45(* *)$ & $0.6(* *)$ & 1 & $0.33(* *)$ & $-0.23(* *)$ \\
\hline
\end{tabular}



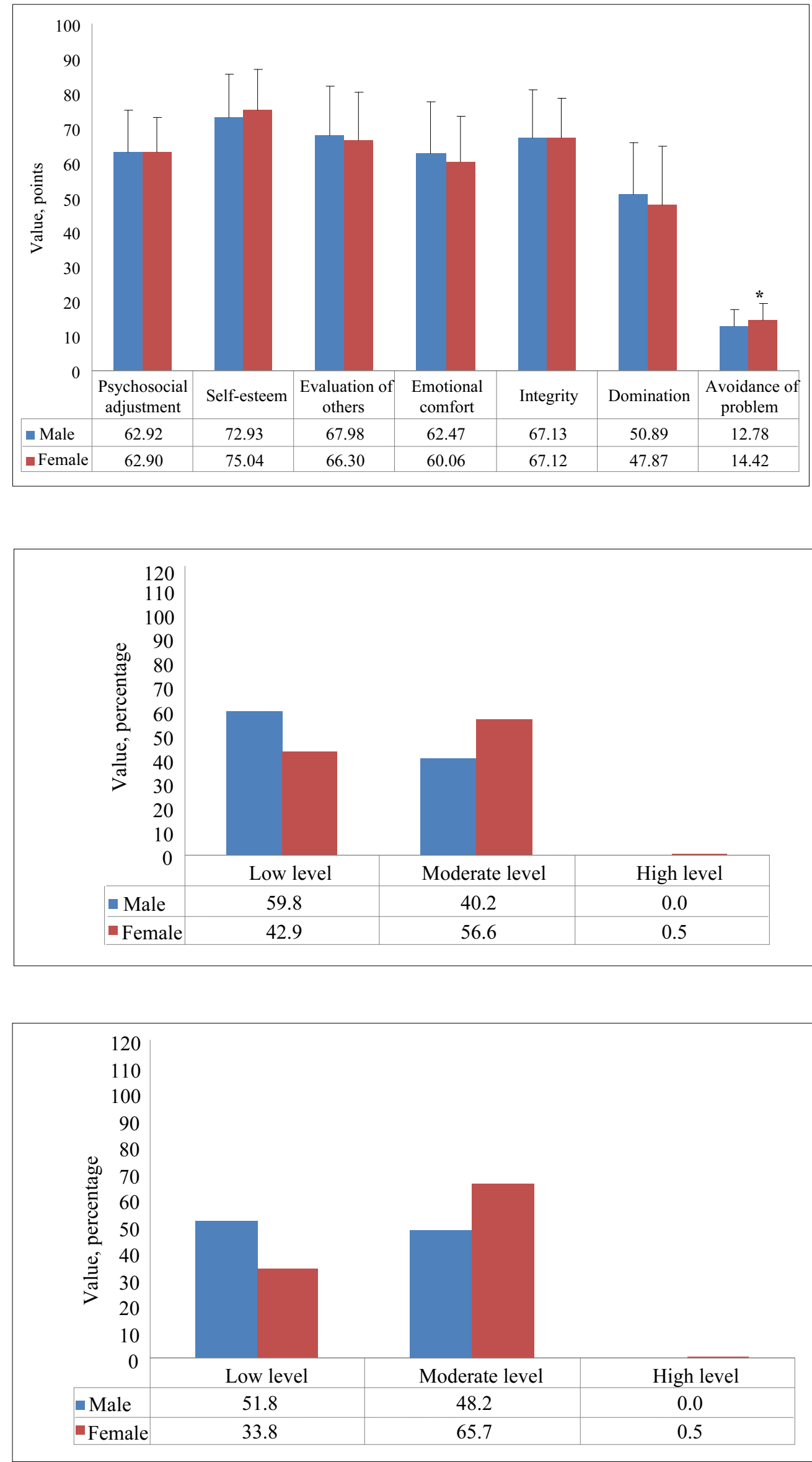

Figure 1. Levels of boys' and girls' psychosocial adjustment and its components (average in points)

Note. $*-p<0.05$ comparing the indices of boys and girls.

Figure 2. Levels of negative evaluation of others for boys and girls, first year gymnasium students (percent)

Note. $\chi^{2}=10.71 ; \mathrm{df}=2$; $\mathrm{p}<0.05$, comparing the levels of negative evaluation of others between girls and boys.

Figure 3. Levels of emotional discomfort for boys and girls, first year gymnasium students (percent)

Note. $\chi^{2}=12.49 ; \mathrm{df}=2$; $\mathrm{p}<0.05$, comparing the levels of emotional discomfort between girls and boys. 


\section{DISCUSSION}

Aiming at revealing the peculiarities of gymnasium first year students' psychosocial adjustment we suggest that our research results do not reveal all the peculiarities of gymnasium first year students' psychosocial adjustment in the whole country, but it allows some insights into certain tendencies, helps reveal preconditions of organizing education which allow targeted process of enhancing psychosocial adjustment and foreseeing rational seeking of pedagogical aims.

Most education researchers have suggested that school plays an important role in the developmental trajectory of students (Jia el al., 2009). K. Osterman (2000) has demonstrated that a relationship exists between connectedness or belonging and academic outcomes. Boys' academic struggles caused by the transition to middle school might be related to feelings of connectedness to the new school. Boys may feel less connected to the new school and, therefore, might not realize themselves as fully academically as girls. At the same time, connectedness may be an adjustment variable that does not capture the decline in self-esteem of girls in transition. Research shows that school anxiety plays a role in determining academic success in boys, whereas work avoidance is an issue for girls (Freudenthaler et al., 2008).

In our research first year gymnasium students showed low levels of psychosocial adjustment $(62.91 \pm 10.91)$. There are studies (Barkauskaite, Mišeikyte, 2006) where similar results have been obtained. The authors argue that difficult psychosocial adjustment of pupils influences unwillingness to learn at school, reduces selfconfidence, the child can turn inwards, lose confidence in teachers, peers, even parents; however, smooth psychosocial adjustment is a strong factor determining pupil's academic success, helping the child develop the attitudes of security, attachment, willingness to achieve more and other attitudes (Barkauskaite, Mišeikytè, 2006). Š. Šniras and R. Malinauskas (2006) maintain that the main things that adolescents lack are better self-esteem, dignity, ability to control emotions, overcome stress and anxiety, constructively solve conflicts and problems. The same results were obtained in our study as well. Self-esteem of adolescents was moderate, avoidance of problems was low. Students facing difficulties in communicating with peers due to various reasons experience seclusion, isolation from the environment while frequent failures in the everyday activity decrease their trust in their own powers (Ellickson, McGuigan, 2000). These students whose adaptation at school and among peers is not fluent and those who experience hard situations in their family and/or home environment, later on transfer their problems to the world of adults (Juodraitis, 2004). It has also been proved that for the proper social adaptation, one needs the support not only of the family, but also of friends (Morano, Cisler, 1993).

We found that the level of negative evaluation of others among first year gymnasium students was statistically significant $(\mathrm{p}<0.05)$ : the average level of negative evaluation of others was more common for girls than for boys. L. Bobrova (2009) suggests that boys adapt to social conditions with more difficulties compared to girls. Girls are more inclined to evaluate others and themselves, and they easier achieve the state of emotional comfort. L. Bobrova (2009) established strong statistically significant correlations between selfevaluation and emotional comfort, self evaluation and domination, domination and falsity. While evaluating the level of emotional discomfort for boys and girls, first year gymnasium students, we found a statistically significant difference in the aspect of gender $(p<0.05)$. Higher levels of emotional discomfort were more common for girls than for boys. C. Wootton (2001) argues that girls are more inclined to adapt than boys. They tend to talk about their problems that interfere with their peace. Boys tend to survive problems themselves because of stereotypes dominating in the society that men are strong, they cannot cry, which means that they cannot tell anybody about their problems. N. J. Wiles et al. (2008) established that children who met recommended levels for physical activity had fewer emotional problems one year later, although the magnitude of this difference was reduced after adjustment for confounders, particularly gender. 


\section{CONCLUSION AND PERSPECTIVES}

We established that psychosocial adjustment of first year gymnasium students was of low level. Such components of psychosocial adjustment as adjustment, evaluation of others, emotional comfort, integrity, domination and avoidance of problems were of low level, and only self-esteem was moderate.
In the aspect of gender, we revealed a statistically significant difference in the avoidance of problems $(p<0.05)$. The avoidance level of girls in the first year of the gymnasium was higher than that of boys. But for boys, the levels of adjustment, evaluation of others, emotional comfort, integrity, domination were higher than those of girls. Selfesteem for girls was higher than that of boys; however, no statistically significant difference was found.

\section{REFERENCES}

Adeyemo, D. A., Ogundokun, M. O. (2010). Emotional intelligence and academic achievement: The moderating influence of age, intrinsic and extrinsic motivation. The African Symposium: An Online Journal of the African Educational Research Network, 10 (2), 127-142.

Barber, B., Olsen, J. (2004). Assessing the transitions to middle and high school. Journal of Adolescent Research, 19, 3-30.

Barkauskaitè, M., Mišeikytė, K. (2006). Mokinių adaptacijos ypatumai kritinių ugdymo(-si) etapų metu. Pedagogika, 84, 127-134.

Barkauskaitè, M. (2000). Paaugliu tarpusavio santykiu sociopedagogine dinamika: habilitacinis darbas. Vilnius: VPU.

Bigelienè, D., Uginčienė, E. (2008). Nacionalinis IV ir VIII klasiu mokiniu pasiekimu tyrimas. Vilnius: Švietimo plètotès centras.

Bobrova, L. (2009). Būsimujų kūno kultūros pedagogu psichosocialinès adaptacijos ypatumai gyvenimo stiliaus kaitos kontekste. Jaunuju mokslininku darbai. Socialiniai mokslai, 1 (22), 24-32.

Ellickson, P. L., McGuigan, K. A. (2000). Early predictors of adolescent violence. American Journal of Public Health, 90, 566-577.

Freudenthaler, H. H., Neubauer, A. C., Gabler, P., Scherl, W. G. ( 2008 ). Testing the Trait Emotional Intelligence Questionnaire (TEIQue) in a German speaking sample. Personality and Individual Differences, 45, 673-678.

Gudynas, P., Bigelienè, D., Dargytė J., Uginčienė, E. (2009). Lietuvos mokyklu tinklas: ar užtikrinamos lygios mokymosi galimybès? Vilnius: UAB „Sapnų sala“.

Harrison, W. D., Jagelavičius, A. (1999). Axioms and assumptions about adaptation: Implications for the social professions. Socialiné-psichologine adaptacija ir švietimo sistema, 1, 14-24.

Jia, Y., Ling, G., Chen, X., Way, N. (2009). The influence of student perceptions of school climate on socioemotional and academic adjustment: A Comparison of Chinese and American adolescents. Child Development, 80 (5), 1514-1530.
Juodraitis, A. (2004). Asmenybés adaptacija: kintamuju sqveika. Šiauliai: Šiaulių universiteto leidykla.

Klizas Š. (2009). Viduriniojo mokyklinio amžiaus moksleiviu psichosocialine adaptacija ir jos stiprinimas per kūno kultūros pamokas: disertacija. Kaunas: LKKA.

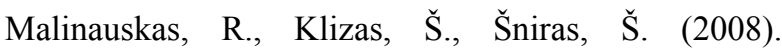
Viduriniojo mokyklinio amžiaus moksleivių socialinè adaptacija kūno kultūros pamokų metu. Ugdymas. Kūno kultūra. Sportas, 2 (69), 52-56.

Malinauskas, R. (2006). Sporto pedagogu ir sportininku socialinio psichologinio rengimo ypatumai: monografija. Kaunas: LKKA.

Midgley, C., Kaplan, A., Middleton, M. et al. ( 2000). The development and validation of scales assessing students' achievement goal orientations. Contemporary Educational Psychology, 23, 113-131.

Morano, C. D., Cisler, R. A. (1993). Risk factors for adolescent suicidal behavior: Loss, insufficient familial support, and hopelessness. Adolescence, 28, 851-865.

Osterman, K. (2000). Students' need for belonging in the school community. Review of Educational Research, 70, 323-367.

Parker, A. K., Neuharth-Pritchett, S. (2009). Sacrificing the present for the future: Elementary teachers and the transition to middle school. Journal of Research in Education, 19, 21-40.

Rogers, C. R., Dymond, R. (1954). Client Centred Therapy: Its Current Practice, Implications and Theory. Houghton Mifflin: Boston Self Image Princeton University Press.

Šniras, ড̌ ., Malinauskas, R. (2006). Jaunujų krepšininku varžybinių psichologiniu igūdžių lygio kaita dèl ugdymo programos poveikio. Sporto mokslas, 2 (44), 31-36.

Wiles, N. J., Jones, G. T., Haase, A. M. et al. (2008). Physical activity and emotional problems amongst adolescents. Social Psychiatry and Psychiatric Epidemiology, 43, 765-772.

Wootton, C. (2001). The Role of Parents in the Development of Adolescent's Emotional Intelligence. Pretoria: Unisa, Unpublished Med Dissertattion. 


\title{
PIRMOS KLASĖS GIMNAZISTU PSICHOSOCIALINĖS ADAPTACIJOS PRIKLAUSOMUMAS NUO LYTIES
}

\author{
Šarūnas Klizas ${ }^{1}$, Irina Kliziené ${ }^{2}$, Vitas Linonis ${ }^{2}$, Daina Miliauskiené ${ }^{3}$ \\ Lietuvos kūno kultūros akademija ${ }^{1}$, Kaunas, Lietuva \\ Kauno technologijos universitetas'2, Kaunas, Lietuva \\ Prienu specialioji mokykla ${ }^{3}$, Prienai, Lietuva
}

\section{SANTRAUKA}

Tyrimo pagrindimas ir hipotezė. Nacionalinių mokiniu pasiekimų tyrimų duomenys patvirtino, kad aukšti mokinių pasiekimai susiję su jų savijauta mokykloje. Ypač reikètų atkreipti dẻmesi i situaciją pirmoje gimnazistų klasèje, kur nustatyti ypač dideli pasiekimų skirtumai tarp palankiai ir nepalankiai mokyklos emocini mikroklimatą ¡vertinusių mokinių. Hipotezuojame, kad pirmos klasės mergaičių gimnazisčių psichosocialinės adaptacijos lygis aukštesnis nei bendraamžių berniukų.

Tikslas - nustatyti pirmos klasės gimnazistų psichosocialinės adaptacijos priklausomumą nuo lyties.

Metodai. Tiriamają imti sudare 362 pirmu gimnazijos klasių mokiniai - mergaičių $(\mathrm{n}=198)$, berniukų $(\mathrm{n}=164)$. Respodentų amžius: 14-16 metų. Tyrimo metu naudota modifikuota K. Rogers ir R. Dymond metodika psichosocialinei adaptacijai tirti. Anketa adaptuota Lietuvos visuomenei tirti (Klizas, 2009). Metodikos autoriu (K. Rogers ir R. Dymond) psichosocialinès adaptacijos modeliu be pagrindinio, psichosocialinę adaptaciją apibūdinančio rodiklio, pateikiamos subskalès (savęs vertinimas, požiūris ị kitus, emocinis komfortas, integralumas, dominavimas, problemu vengimas), padedančios atskleisti psichosocialinę asmenybès adaptaciją.

Rezultatai. Analizuojant pirmos klasès gimnazistų psichosocialinès adaptacijos lygi lyties požiūriu, nustatytas statistiškai patikimas problemų vengimo skirtumas $(t=-3,19 ; \mathrm{p}<0,05)$. Išsiaiškinome, kad pirmos klasės gimnazistų ir gimnazisčių neigiamo požiūrio i kitus lygis statistiškai patikimas $\left(\chi^{2}=10,71 ; 1 l s=2 ; p<0,05\right)$. Vertinant pirmos klasès gimnazistų berniukų ir mergaičiu emocinio diskomforto lygi, nustatytas patikimas skirtumas lyties požiūriu $\left(\chi^{2}=12,49 ; 11 \mathrm{~s}=2 ; \mathrm{p}<0,05\right)$.

Aptarimas ir išvados. Nustatėme, kad pirmos klasės gimnazistų psichosocialinė adaptacija yra žemo lygio. Psichosocialinę adaptaciją sudarantys komponentai (adaptacija, požiūris i kitus, emocinis komfortas, internalumas, dominavimas, problemų vengimas) yra žemo lygio ir tik savęs vertinimas yra vidutinis. Išanalizavus pirmos klasės gimnazistų psichosocialinès adaptacijos lygi lyties požiūriu, nustatytas statistiškai patikimas problemų vengimo skirtumas $(\mathrm{p}<0,05)$. Tirtų mergaičių gimnazisčiu problemų vengimo lygis yra didesnis negu berniukų gimnazistų. Visgi berniukų adaptacijos, požiūrio į kitus, emocinio komforto, internalumo, dominavimo lygiai aukštesni negu mergaičių. Gimnazisčių mergaičių savęs vertinimas yra aukštesnis negu berniukų gimnazistų, tačiau statistiškai patikimo skirtumo nenustatyta.

Raktažodžiai: savijauta (adaptacija) mokykloje, emocinis komfortas, problemų vengimas.

Corresponding author Šarūnas Klizas

Lithuanian Academy of Physical Education Sporto str. 6, LT-44221 Kaunas

Lithuania

Tel +370 37209050

E-mails.klizas@lkka.lt 